\title{
Acquired coarctation of abdominal aorta by hydatid disease
}

\author{
I-Chin Lee, Qian Lu
}

Hepato-Pancreato-Biliary Center, Beijing Tsinghua Changgung Hospital, School of Clinical Medicine, Tsinghua University, Beijing, China Correspondence to: Qian Lu, MD, PhD. Hepato-Pancreato-Biliary Center, Beijing Tsinghua Changgung Hospital, School of Clinical Medicine, Tsinghua University, No. 168, Li-Tang Road, Beijing 102218, China. Email: luqianbtch@163.com.

Submitted Oct 09, 2020. Accepted for publication Nov 27, 2020.

doi: 10.21037/hbsn-20-743

View this article at: https://dx.doi.org/10.21037/hbsn-20-743
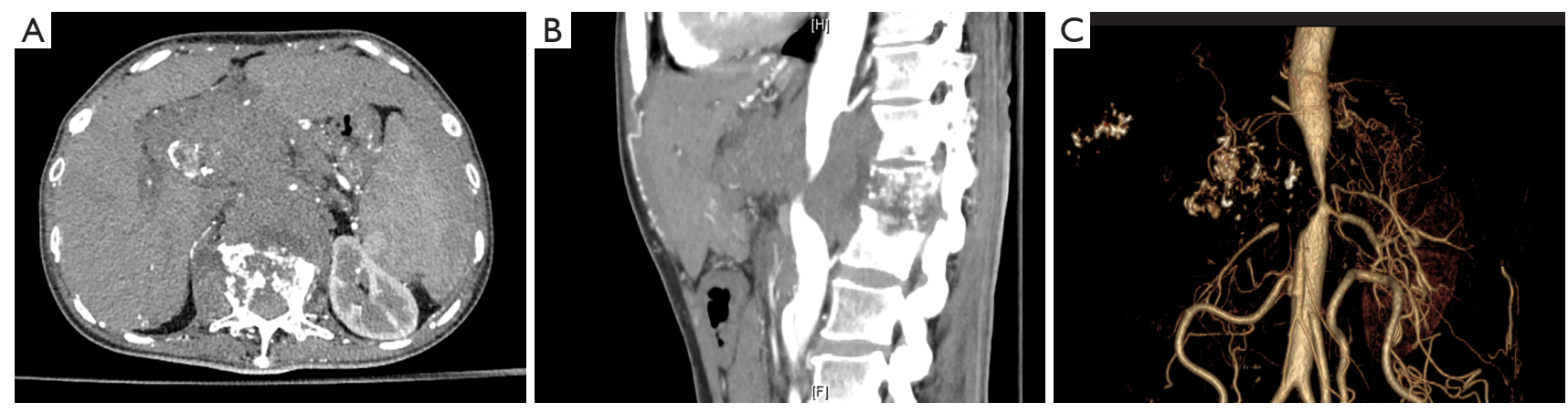

A 45-year-old woman presented to the hospital with severe back pain, inability to stand, and increased blood pressure for 4 months. She had been diagnosed with hepatic hydatid disease 4 years ago but refused any treatment. Physical examination revealed an upper limb blood pressure of $199 / 104 \mathrm{mmHg}$, compared to the lower limb's 113/80 mmHg. CT scans discovered a large hilar mass involved in the abdominal aorta (Panel 1A), pathologic fractures of the T12-L2 vertebras (Panel 1B), and the coarctation of abdominal aorta at the L1 vertebra level (Panel 1C). The patient was treated with Urapidil and Nifedipine for hypertension and Albendazole for hydatid disease. After the blood pressure was controlled at $150 / 100 \mathrm{mmHg}$, the patient underwent laminectomy and fusion. Pathological examination confirmed alveolar echinococcosis (AE). The patient was able to walk 3 months after the surgery but died 1 year after the presentation due to disease progression.

\section{Acknowledgments}

Song-Hua Xiao MD, Su-Xi Gu MD, and Dong-Hu MD performed the orthopedic surgery. We thank Chia-Yung Lee for language editing assistance, and Tzu-Hua Lee for technical help.

Funding: None.

\section{Footnote}

Provenance and Peer Review: This article is a standard submission to the editorial office, Hepatobiliary Surgery and Nutrition. The article did not undergo external peer review.

Conflicts of Interest: Both authors have completed the ICMJE uniform disclosure form (available at https://hbsn. amegroups.com/article/view/10.21037/hbsn-20-743/coif). The authors have no conflicts of interest to declare.

Ethical Statement: The authors are accountable for all aspects of the work in ensuring that questions related to the accuracy or integrity of any part of the work are appropriately investigated and resolved. Written informed consent was obtained from the patient for publication of this manuscript and any accompanying images.

Open Access Statement: This is an Open Access article distributed in accordance with the Creative Commons 
Attribution-NonCommercial-NoDerivs 4.0 International License (CC BY-NC-ND 4.0), which permits the noncommercial replication and distribution of the article with the strict proviso that no changes or edits are made and the

Cite this article as: Lee IC, Lu Q. Acquired coarctation of abdominal aorta by hydatid disease. HepatoBiliary Surg Nutr 2021;10(5):744-745. doi: 10.21037/hbsn-20-743 original work is properly cited (including links to both the formal publication through the relevant DOI and the license). See: https://creativecommons.org/licenses/by-nc-nd/4.0/. 